\title{
Synthesis, Characterisation and Luminescent Properties of Lanthanide-Organic Polymers with Picolinic and Glutaric Acids
}

\author{
Penka I. Girginova, ${ }^{\text {[a] }}$ Filipe A. Almeida Paz, ${ }^{\text {[a] }}$ Paula C. R. Soares-Santos, ${ }^{\text {[a] }}$ \\ R. A. Sá Ferreira, ${ }^{[b]}$ Luís D. Carlos, ${ }^{[b]}{ }^{[1}$ ítor S. Amaral, ${ }^{[b]}$ Jacek Klinowski, ${ }^{[c]}$ \\ Helena I. S. Nogueira, ${ }^{[a]}$ and Tito Trindade ${ }^{*[a]}$
}

Keywords: Lanthanide complexes / Picolinic acid / Glutaric acid / Luminescence

Three new lanthanide(III) complexes ( $\mathrm{Ln}=\mathrm{Sm}$, Tb and Eu) of picolinic and glutaric acid were prepared and characterised. The crystal structure of the complex [Sm(glu)(pic)$\left(\mathrm{H}_{2} \mathrm{O}\right)_{2}$ ] (where Hpic and $\mathrm{H}_{2}$ glu stand for picolinic and glutaric acid, respectively) was determined by single-crystal Xray diffraction. All the Ln complexes were characterised by elemental analysis, infrared spectroscopy, X-ray powder diffraction and thermoanalytical measurements. The combined data show that these Ln complexes are isostructural. The effect of both organic ligands on the photoluminescent behaviour of the $\mathrm{Sm}^{3+}, \mathrm{Eu}^{3+}$ and $\mathrm{Tb}^{3+}$ complexes is discussed and we anticipate the possibility of controlling the photoluminescence of picolinic-containing lanthanide compounds by systematically varying the length of the bridging ligand.

(ङ Wiley-VCH Verlag GmbH \& Co. KGaA, 69451 Weinheim, Germany, 2007)

\section{Introduction}

The design of functional units from the molecular scale to macroscopic assemblies has emerged as a new paradigm in materials synthesis resulting in an interplay between conventional molecular chemistry and conventional solid-state science. This has been particularly clear in the development of functional materials using coordination compounds such as in the field of semiconductors technology, supramolecular machinery, microporous and hybrid materials and catalysis. ${ }^{[1]}$ In some cases, the development of these functional materials is based on the chemistry of well-known coordination compounds as illustrated by the assembly of inorganic-organic extended lattices ${ }^{[2]}$ and in the thermolysis of metal thiolato compounds to produce thin films or nanoparticles. ${ }^{[3]}$

Metals coordinated to aromatic ambidentate ligands form a class of compounds with a wide variety of coordination modes which has long attracted the attention of chemists. ${ }^{[4]}$ Griffith and co-workers extended this type of chemistry to the second row transition metals and, in particular,

[a] Department of Chemistry, University of Aveiro, CICECO, 3810-193 Aveiro, Portugal

Fax: +351-234-370-084

E-mail: ttrindade@dq.ua.pt

[b] Department of Physics, University of Aveiro, CICECO, 3810-193 Aveiro, Portugal

[c] Department of Chemistry, University of Cambridge, Lensfield Road, CB2 1EW Cambridge, United Kingdom

$\square$ Supporting information for this article is available on the WWW under http://www.eurjic.org or from the author. to their applications in catalysis. ${ }^{[5]}$ More recently, as part of our own studies of metal complexes with aromatic ambidentate ligands, ${ }^{[6]}$ we began to exploit the coordination chemistry of 3-hydroxypicolinic acid and its derivatives in the synthesis of a series of lanthanide complexes and we investigated the role of this ligand in the photoluminescence of such complexes. ${ }^{[7]}$ Picolinic acid complexes of lanthanides, particularly those of $\mathrm{Eu}^{3+}$ and $\mathrm{Tb}^{3+}$, show interesting photoluminescent behaviour because energy transfer from the aromatic groups close to the lanthanide ions may enhance the luminescent efficiency of the ion. ${ }^{[8]}$ Even dispersed in solid matrices they can produce efficient luminescent materials, such as those in $\mathrm{SiO}_{2}$ nanoparticles obtained by the sol-gel method. ${ }^{[7]}$ Therefore, in principle, it should be possible to fine tune the luminescence of such nanocomposites by working out the coordination chemistry of the Ln complexes. Lanthanide coordination polymers, including those synthesised in the presence of dicarboxylato ligands have attracted considerable interest and many examples can be found in the literature. ${ }^{[9]}$ However, we could not find examples of Ln-containing coordination compounds with this type of ligand or an aromatic antenna. Consequently, we report here a distinct approach which involves the simultaneous use of a highly flexible bridging ligand (glutaric acid) with a chelating aromatic ligand (picolinic acid) which, on the one hand, might function as an antenna, efficiently transferring energy to the Ln centre or, on the other hand, may remove available coordination sites thus controlling to some extent the dimensionality of the final product. 


\section{Results and Discussion}

\section{Synthetic Aspects}

Lanthanide-organic coordination polymers, with the general empirical formula $\left[\mathrm{Ln}(\mathrm{glu})(\mathrm{pic})\left(\mathrm{H}_{2} \mathrm{O}\right)_{2}\right]\left(\right.$ where $\mathrm{Ln}^{3+}=$ $\mathrm{Sm}^{3+}, \mathrm{Tb}^{3+}$ and $\left.\mathrm{Eu}^{3+}\right)$, have been prepared by reaction, in aqueous media, of the respective Ln nitrato salts with glutaric $\left(\mathrm{H}_{2}\right.$ pic) and picolinic (Hpic) acids (see Exp. Sect.). Such a procedure invariably yielded microcrystalline powders. Thus, the reaction with $\mathrm{Sm}^{3+}$ was allowed to proceed slowly in a silica gel matrix over a period of several months, leading to high-quality single-crystals suitable for a full structural determination using X-ray diffraction (see crystal description below). Phase identification of the $\mathrm{Tb}^{3+}$ material was also performed using single-crystal X-ray diffraction whereas for the $\mathrm{Eu}^{3+}$ complex only powder studies could be undertaken (see Exp. Sect. dedicated to X-ray crystallography and the Supporting Information). Crystal images of the $\mathrm{Sm}^{3+}$ (SEM) and $\mathrm{Tb}^{3+}$ (optical microscope) compounds are supplied as Supporting Information.

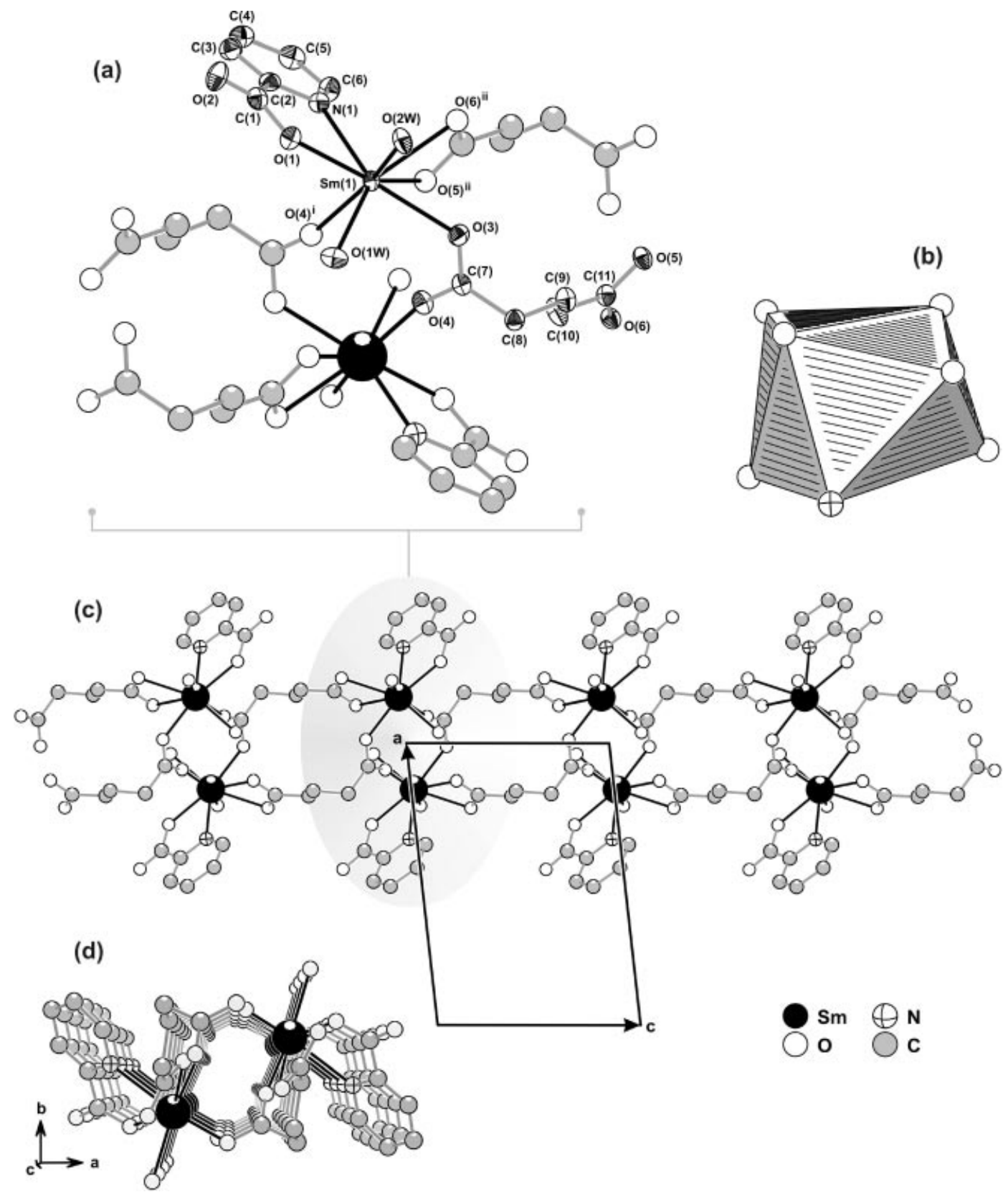

Figure 1. (a) Centrosymmetric binuclear secondary building unit of the coordination polymer, showing the labelling scheme for all nonhydrogen atoms belonging to the asymmetric unit. Thermal ellipsoids are shown at the $50 \%$ probability level. (b) Polyhedral representation of the coordination sphere of the $\mathrm{Sm}^{3+}$ centre, $\left\{\mathrm{SmNO}_{7}\right\}$, resembling a highly distorted dodecahedron. (c and d) Perspective views of the $1 \mathrm{D}{ }_{\infty}^{1}\left[\mathrm{Sm}(\mathrm{glu})(\mathrm{pic})\left(\mathrm{H}_{2} \mathrm{O}\right)_{2}\right]$ molecular tape running parallel to the $c$ axis of the unit cell. Hydrogen atoms have been omitted for clarity. For selected bond lengths and angles see Table 1. Symmetry transformations used to generate equivalent atoms: (i) $2-x, 1-y,-z$; (ii) $2-x, 1-y, 1-z$. 


\section{Crystal Structure Description of $\left[\mathrm{Sm}(\mathrm{glu})(\mathrm{pic})\left(\mathrm{H}_{2} \mathrm{O}\right)_{2}\right]$}

When an aqueous solution containing $\mathrm{Sm}^{3+}$ diffuses into a gel containing glutaric acid $\left(\mathrm{H}_{2}\right.$ glu $\left.=\mathrm{C}_{5} \mathrm{H}_{8} \mathrm{O}_{4}\right)$ and picolinic acid $\left(\mathrm{Hpic}=\mathrm{C}_{6} \mathrm{H}_{5} \mathrm{NO}_{2}\right)$ a crystalline material, which could be manually isolated in the form of large single-crystals, formed after a period of 4 months (see Exp. Sect.). The crystal structure of this material was elucidated by X-ray crystallography (see dedicated Exp. Sect.) and ultimately formulated as $\left[\mathrm{Sm}(\mathrm{glu})(\mathrm{pic})\left(\mathrm{H}_{2} \mathrm{O}\right)_{2}\right]$. The phase purity and homogeneity of the bulk sample were further confirmed using powder X-ray diffraction (not shown) and CHN elemental composition analyses.

The crystal structure contains a single crystallographically unique $\mathrm{Sm}^{3+}$ metallic centre which appears coordinated to two water molecules, three glutarate anions $\left(\mathrm{glu}^{2-}\right)$ and one picolinic acid residue ( pic $^{-}$) in a typical eight-coordination fashion (see part a of Figure 1, $\left\{\mathrm{SmNO}_{7}\right\}$ ) best described as a highly distorted dodecahedron (Figure 1, b): while one trapezoid of this polyhedron is composed of two water molecules $[\mathrm{O}(1 \mathrm{~W})$ and $\mathrm{O}(2 \mathrm{~W})]$ and two oxygen atoms from distinct glutarato residues $\left[\mathrm{O}(4)^{\mathrm{i}}\right.$ and $\left.\mathrm{O}(6)^{\mathrm{i}}\right]$, the other is instead formed from the N,O-chelate of the picolinic acid moiety plus another two oxygen atoms from glutarate anions $\left[\mathrm{O}(3)\right.$ and $\left.\mathrm{O}(5)^{\mathrm{ii}}\right]$ (Figure 1, a and b; symmetry codes: (i) $2-x, 1-y,-z$; (ii) $2-x, 1-y, 1-z$ ). The $\mathrm{Sm}-$ $\mathrm{O}$ bond lengths for the coordinated water molecules and the carboxylato groups [found in the 2.407(3)-2.410(3) and 2.355(3)-2.508(3) Å ranges, respectively - see Table 1] are in good agreement with those typically found in related compounds, as revealed by a search of the Cambridge Structural Database (CSD, Version 5.27, November 2005), ${ }^{[10,11]}$ while the typical $\mathrm{Sm}-\mathrm{O}_{\text {water }}$ distance can be found in the 2.32-2.89 A range (from 41 entries with a median of $2.44 \AA$ ). The $\mathrm{Sm}-\mathrm{O}_{\text {carboxylate }}$ are instead in the 2.19-3.08 $\AA$ range (from 98 entries with a median of $2.41 \AA$ ). It is of considerable interest to mention that the lack of regularity in the dodecahedral coordination environment arises, mainly, because of the various binding modes of the ligands composing the first coordination sphere (details in the following paragraphs) which is directly reflected in the internal angles of the polyhedron (Table 1).

The compound contains a single crystallographically independent glutarato residue which appears with its two carboxylato groups having very distinct coordination modes (Scheme 1). On the one hand, the carboxylato group composed of $\mathrm{O}(5)$ and $\mathrm{O}(6)$ (Figure 1, a) coordinates to the $\mathrm{Sm}^{3+}$ centre through a typical bidentate syn,syn chelating fashion with a bite angle of 52.33(9) ${ }^{\circ}$ which is in good agreement with the values reported for analogous materials (from 35 entries in the CSD with a median of $51.2^{\circ}$ ). On the other hand, the opposite carboxylato group, composed of $\mathrm{O}(3)$ and $\mathrm{O}(4)$ (Figure 1, a), appears instead forming a syn,anti bridge with a neighbouring $\mathrm{Sm}^{3+}$ cation, thus imposing a $\operatorname{Sm}(1) \cdots \operatorname{Sm}(1)^{\mathrm{i}}$ separation of $4.626(1) \AA$. This syn, anti bridge leads to the formation of a centrosymmetric binuclear moiety which can be further envisaged as the building block of the polymeric structure of the material (see below), a structural feature only found in a handful of other structures also containing lanthanide centres and glutarato anions, namely with $\mathrm{Nd}^{3+},{ }^{[12,13]} \mathrm{Ho}^{3+}{ }^{[13]}$ and $\mathrm{Tb}^{3+},{ }^{114]}$ all of which are 1D materials. Interestingly, in those compounds, the glutarato anions exhibit markedly distinct coordination geometries compared with those recorded for our material. This is particularly notable for the bridging groups which appear as syn,anti bridges while in those related 1D compounds ${ }^{[12,13]}$ one oxygen atom is simultaneously involved in a syn,syn chelate and in a syn,anti bridge. Moreover, this structural aspect exhibited by one carboxylato oxygen atom is repeatedly found in all the remaining known $2_{-[14]}$ and $3 \mathrm{D}^{[15-21]}$ lanthanide-organic materials containing glutaric acid residues, thus rendering the present compound the first example of a glutaratolanthanide material in which an inter-lanthanide bridge via a carboxylato group is enforced by a syn,anti bridge. Apart from structurally creating the aforementioned bimetallic

Table 1. Selected bond lengths $[\AA]$ and angles $\left[{ }^{\circ}\right]$ for the $\mathrm{Sm}^{3+}$ coordination environment present in $\left[\mathrm{Sm}(\mathrm{glu})(\mathrm{pic})\left(\mathrm{H}_{2} \mathrm{O}\right)_{2}\right] .^{[\mathrm{a}]}$

\begin{tabular}{|c|c|c|c|}
\hline $\mathrm{Sm}(1)-\mathrm{O}(1)$ & $2.355(3)$ & $\mathrm{Sm}(1)-\mathrm{O}(6)^{\mathrm{ii}}$ & $2.508(3)$ \\
\hline $\mathrm{Sm}(1)-\mathrm{O}(3)$ & $2.452(3)$ & $\mathrm{Sm}(1)-\mathrm{O}(1 \mathrm{~W})$ & $2.407(3)$ \\
\hline $\operatorname{Sm}(1)-O(4)^{i}$ & $2.358(3)$ & $\mathrm{Sm}(1)-\mathrm{O}(2 \mathrm{~W})$ & $2.410(3)$ \\
\hline $\mathrm{Sm}(1)-\mathrm{O}(5)^{\mathrm{ii}}$ & $2.461(3)$ & $\operatorname{Sm}(1)-N(1)$ & $2.624(3)$ \\
\hline $\mathrm{O}(1)-\mathrm{Sm}(1)-\mathrm{O}(3)$ & $141.54(10)$ & $\mathrm{O}(4)^{\mathrm{i}}-\mathrm{Sm}(1)-\mathrm{O}(1 \mathrm{~W})$ & $74.40(10)$ \\
\hline $\mathrm{O}(1)-\mathrm{Sm}(1)-\mathrm{O}(4)^{\mathrm{i}}$ & $90.50(10)$ & $\mathrm{O}(4)^{\mathrm{i}}-\mathrm{Sm}(1)-\mathrm{O}(2 \mathrm{~W})$ & $155.34(11)$ \\
\hline $\mathrm{O}(1)-\mathrm{Sm}(1)-\mathrm{O}(5)^{\mathrm{ii}}$ & $140.99(10)$ & $\mathrm{O}(5)^{\mathrm{ii}}-\mathrm{Sm}(1)-\mathrm{O}(6)^{\mathrm{ii}}$ & $52.33(9)$ \\
\hline $\mathrm{O}(1)-\mathrm{Sm}(1)-\mathrm{O}(6)^{\mathrm{ii}}$ & $120.16(10)$ & $\mathrm{O}(5)^{\mathrm{ii}}-\mathrm{Sm}(1)-\mathrm{N}(1)$ & $76.10(10)$ \\
\hline $\mathrm{O}(1)-\mathrm{Sm}(1)-\mathrm{N}(1)$ & $64.97(10)$ & 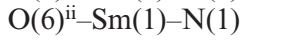 & $81.25(11)$ \\
\hline $\mathrm{O}(1)-\mathrm{Sm}(1)-\mathrm{O}(1 \mathrm{~W})$ & $77.48(10)$ & $\mathrm{O}(1 \mathrm{~W})-\mathrm{Sm}(1)-\mathrm{O}(3)$ & $77.89(11)$ \\
\hline $\mathrm{O}(1)-\mathrm{Sm}(1)-\mathrm{O}(2 \mathrm{~W})$ & $72.55(10)$ & $\mathrm{O}(1 \mathrm{~W})-\mathrm{Sm}(1)-\mathrm{O}(5)^{\mathrm{ii}}$ & $131.92(10)$ \\
\hline $\mathrm{O}(3)-\mathrm{Sm}(1)-\mathrm{O}(5)^{\mathrm{ii}}$ & $76.61(10)$ & $\mathrm{O}(1 \mathrm{~W})-\mathrm{Sm}(1)-\mathrm{O}(6)^{\mathrm{ii}}$ & $146.77(10)$ \\
\hline $\mathrm{O}(3)-\mathrm{Sm}(1)-\mathrm{O}(6)^{\mathrm{ii}}$ & $71.56(10)$ & $\mathrm{O}(1 \mathrm{~W})-\mathrm{Sm}(1)-\mathrm{O}(2 \mathrm{~W})$ & $84.31(11)$ \\
\hline $\mathrm{O}(3)-\mathrm{Sm}(1)-\mathrm{N}(1)$ & $149.60(11)$ & $\mathrm{O}(1 \mathrm{~W})-\mathrm{Sm}(1)-\mathrm{N}(1)$ & $131.30(11)$ \\
\hline $\mathrm{O}(4)^{\mathrm{i}}-\mathrm{Sm}(1)-\mathrm{O}(3)$ & $110.58(10)$ & $\mathrm{O}(2 \mathrm{~W})-\mathrm{Sm}(1)-\mathrm{O}(3)$ & $76.03(10)$ \\
\hline $\mathrm{O}(4)^{\mathrm{i}}-\mathrm{Sm}(1)-\mathrm{O}(5)^{\mathrm{ii}}$ & $77.47(10)$ & $\mathrm{O}(2 \mathrm{~W})-\mathrm{Sm}(1)-\mathrm{O}(5)^{\mathrm{ii}}$ & $126.89(10)$ \\
\hline $\mathrm{O}(4)^{\mathrm{i}}-\mathrm{Sm}(1)-\mathrm{O}(6)^{\mathrm{ii}}$ & $128.57(10)$ & $\mathrm{O}(2 \mathrm{~W})-\mathrm{Sm}(1)-\mathrm{O}(6)^{\mathrm{ii}}$ & $76.05(10)$ \\
\hline $\mathrm{O}(4)^{\mathrm{i}}-\mathrm{Sm}(1)-\mathrm{N}(1)$ & 76.04(11) & $\mathrm{O}(2 \mathrm{~W})-\mathrm{Sm}(1)-\mathrm{N}(1)$ & $110.80(11)$ \\
\hline
\end{tabular}

[a] Symmetry transformations used to generate equivalent atoms: (i) $2-x, 1-y,-z$; (ii) $2-x, 1-y, 1-z$. 
units, the glutarato anionic residues further establish physical links interconnecting the two $\mathrm{Sm}^{3+}$ centres of one unit $\left[\operatorname{Sm}(1)\right.$ plus $\operatorname{Sm}(1)^{\mathrm{i}}-$ Figure 1, a] with a third metallic centre of a neighbouring moiety $\left[\mathrm{Sm}(1)^{\mathrm{iii}}\right]$, imposing $\operatorname{Sm}(1)^{\cdots} \cdots$ $\operatorname{Sm}(1)^{\mathrm{iii}}$ and $\operatorname{Sm}(1)^{\mathrm{i}} \cdots \operatorname{Sm}(1)^{\mathrm{iii}}$ separations of $8.480(2)$ and 9.074(2) A, respectively [symmetry code: (iii) $x, y,-1+z$ ]. This leads to the formation of a $1 \mathrm{D} \infty{ }_{\infty}^{1}\left[\mathrm{Sm}(\mathrm{glu})(\mathrm{pic})\left(\mathrm{H}_{2} \mathrm{O}\right)_{2}\right]$ molecular tape running parallel to the [001] direction of the unit cell (Figure 1, c and d).

\section{(a)}

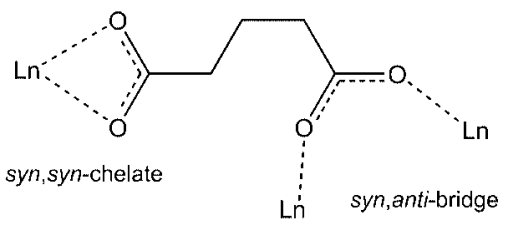<smiles>O=C1O[Al]N2C=CC=CC12O</smiles>

Scheme 1. Coordination modes of the ligands present in $[\mathrm{Sm}(\mathrm{glu})$ (pic) $\left(\mathrm{H}_{2} \mathrm{O}\right)_{2}$ ]: (a) glutaric acid; (b) picolinic acid.

As reported by Zhang et al. ${ }^{[13]}$ for the 1D ${ }_{\infty}^{1}[\mathrm{Ln}(\mathrm{glu})($ phen $) \mathrm{Cl}]$ (where $\mathrm{Ln}^{3+}=\mathrm{Tb}^{3+}$ and $\mathrm{Ho}^{3+}$, phen $=$ 1,10-phenanthroline) materials, the ${ }_{\infty}^{1}\left[\mathrm{Sm}(\mathrm{glu})(\mathrm{pic})\left(\mathrm{H}_{2} \mathrm{O}\right)_{2}\right]$ molecular tape present in the crystal structure also contains, external to the glu/Sm core, chelating aromatic organic ligands (picolinato residues) which seem to prevent the growth of the hybrid polymer in more than one direction by removing available coordination sites in the metallic centres (Figure 1). Indeed for all known and related compounds, when these chelating moieties are not present, 2-[14] and $3 \mathrm{D}^{[15-22]}$ materials are typically isolated. The picolinic acid residues appear coordinated to the $\mathrm{Sm}^{3+}$ metallic centres in a typical N,O-chelating fashion (Scheme 1) with a bite angle of $64.97(10)^{\circ}$, a value consistent with those reported for similar compounds ${ }^{[23-26]}$ (10 entries in the CSD, with values spanning from 60.5 to $67.6^{\circ}$; median of $\left.64.0^{\circ}\right)$.

Individual neutral 1D ${ }_{\infty}^{1}\left[\mathrm{Sm}(\mathrm{glu})(\mathrm{pic})\left(\mathrm{H}_{2} \mathrm{O}\right)_{2}\right]$ molecular tapes close-pack in the solid state, mediated by weak interactions such as homonuclear $\mathrm{O}-\mathrm{H} \cdot \cdots \mathrm{O}$ hydrogen bonds and $\pi-\pi$ stacking to form a $3 \mathrm{D}$ supramolecular structure. On the one hand, strong and highly directional [all interaction angles $<$ (DHA) are well above $150^{\circ}$ - see Table 2] $\mathrm{O}-\mathrm{H} \cdots \mathrm{O}$ hydrogen bonds involving the coordinated water molecules and the carboxylato groups interconnect neighbouring tapes in the $b c$ plane of the unit cell leading to a $2 \mathrm{D}$ supramolecular framework (Figure 2, a). One of these interactions is particularly important for the structural integrity of the binuclear secondary building unit of the molecular tape, as represented in Figure 2 (b). The coordinated $\mathrm{O}(1 \mathrm{~W})$ water molecule donates one hydrogen atom in a strong hydrogen bonding interaction with a neighbouring carboxylato group $\left[\mathrm{D} \cdots \mathrm{A}\right.$ of $2.753(4) \AA$ with $<(\mathrm{DHA})$ of $\left.175(4)^{\circ}\right]$. In fact, for all other closely related compounds, connections between adjacent lanthanide centres are usually assured by four carboxylato groups, either belonging to the glutarato $^{[12-14,16,18-21]}$ or oxalato ${ }^{[15,17]}$ anions in a pseudo-paddlewheel motif. For the ${ }_{\infty}^{1}\left[\mathrm{Sm}(\mathrm{glu})(\mathrm{pic})\left(\mathrm{H}_{2} \mathrm{O}\right)_{2}\right]$ molecular tape, only two carboxylato groups bridge the metallic centres (Figure 2, b) with structural stability being achieved

Table 2. Hydrogen bonding geometry (distances in $\AA$ and angles in ${ }^{\circ}$ ) for $\left[\mathrm{Sm}(\mathrm{glu})(\mathrm{pic})\left(\mathrm{H}_{2} \mathrm{O}\right)_{2}\right]^{[\mathrm{a}]}$

\begin{tabular}{lll}
\hline $\mathrm{D}-\mathrm{H} \cdots \mathrm{A}$ & $d(\mathrm{D} \cdots \mathrm{A})$ & $<(\mathrm{DHA})$ \\
\hline $\mathrm{O}(1 \mathrm{~W})-\mathrm{H}(1 \mathrm{~A}) \cdots \mathrm{O}(5)^{\mathrm{iii}}$ & $2.753(4)$ & $175(4)$ \\
$\mathrm{O}(1 \mathrm{~W})-\mathrm{H}(1 \mathrm{~B}) \cdots \mathrm{O}(3)^{\mathrm{iv}}$ & $2.687(4)$ & $174(4)$ \\
$\mathrm{O}(2 \mathrm{~W})-\mathrm{H}(2 \mathrm{~A}) \cdots \mathrm{O}(6)^{\mathrm{v}}$ & $2.842(4)$ & $159(5)$ \\
$\mathrm{O}(2 \mathrm{~W})-\mathrm{H}(2 \mathrm{~B}) \cdots \mathrm{O}(1)^{\mathrm{vi}}$ & $2.764(4)$ & $172(4)$ \\
\hline
\end{tabular}

[a] Symmetry transformations used to generate equivalent atoms: (iii) $x, y,-1+z$; (iv) $x, 1 / 2-y,-1 / 2+z$; (v) $2-x,-1 / 2+y, 1 / 2-z$; (vi) $x, 1 / 2-y, 1 / 2+z$

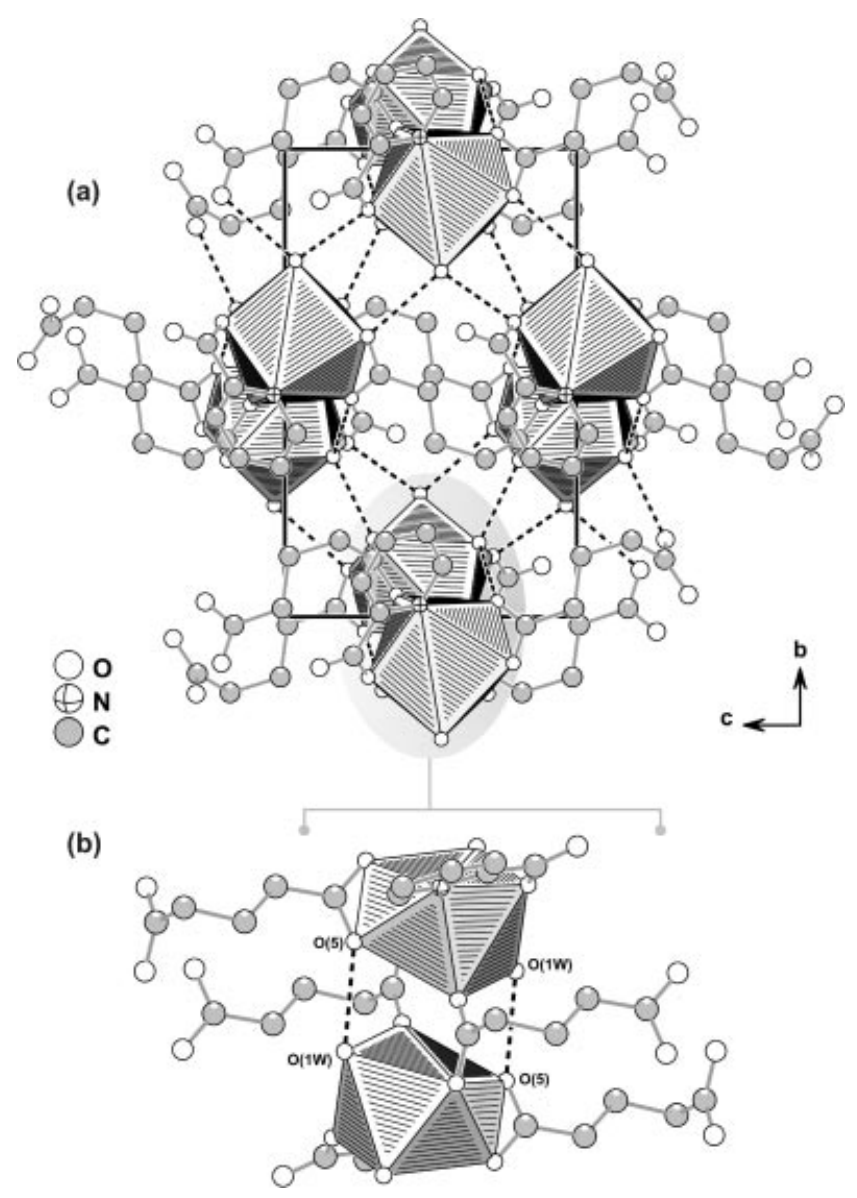

Figure 2. (a) Crystal packing of $\left[\mathrm{Sm}(\mathrm{glu})(\mathrm{pic})\left(\mathrm{H}_{2} \mathrm{O}\right)_{2}\right]$ viewed along the [100] direction of the unit cell. (b) Intra-dimer hydrogen bonds involving the coordinated $\mathrm{O}(1)$ water molecule and the syn,syn chelating carboxylato group. Hydrogen atoms and symmetry codes used to generate equivalent atoms have been omitted for clarity. Hydrogen bonds are represented as black-filled dashed lines. For hydrogen bonding geometric details see Table 2 . 
when the aforementioned hydrogen bonds are taken into account. Hydrogen-bonded supramolecular layers are in turn arranged in an orderly fashion along the [100] direction of the unit cell, mediated by offset $\pi-\pi$ stacking interactions between neighbouring coordinated picolinic acid residues (Figure 3).

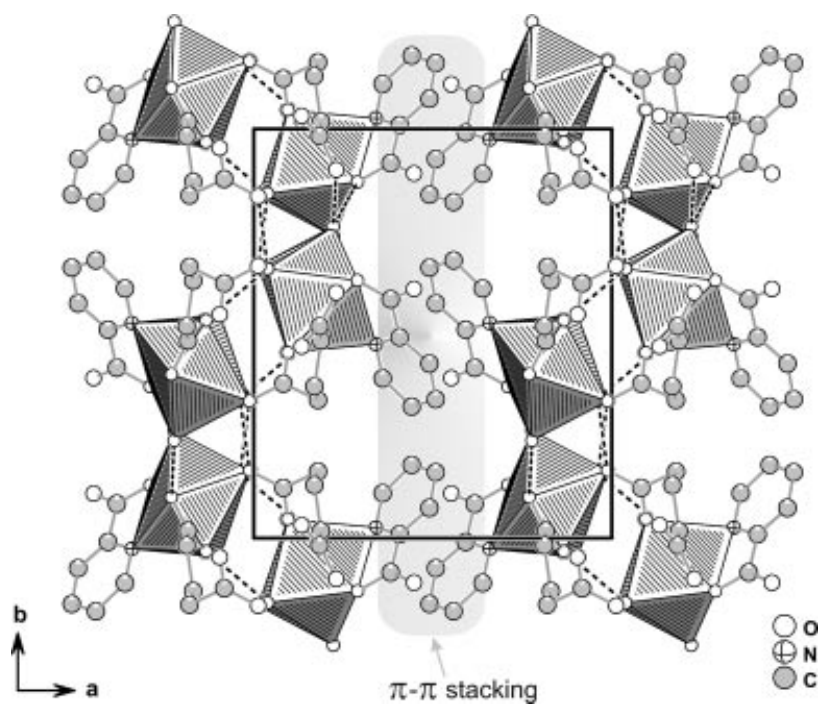

Figure 3. Mixed ball-and-stick and polyhedral (for the $\left\{\mathrm{SmNO}_{7}\right\}$ coordination environments) representations of the crystal packing of $\left[\mathrm{Sm}(\mathrm{glu})(\mathrm{pic})\left(\mathrm{H}_{2} \mathrm{O}\right)_{2}\right]$ viewed along [001] direction of the unit cell. Hydrogen atoms have been omitted for clarity and hydrogen bonds are represented as black-filled dashed lines.

\section{Spectroscopic and Thermoanalytical Results}

The CHN elemental data for $\left[\mathrm{Ln}(\mathrm{glu})(\mathrm{pic})\left(\mathrm{H}_{2} \mathrm{O}\right)_{2}\right]$ (where $\mathrm{Ln}=\mathrm{Sm}^{3+}, \mathrm{Tb}^{3+}$ and $\mathrm{Eu}^{3+}$ ) are summarised in Table 3 and agree well with the expected compositions based on the single-crystal X-ray studies performed (see above). Diagnostic FTIR and Raman spectroscopic data are also provided in Table 3. FTIR spectroscopy confirms the coordination of both ligands to the metal centres: pic $^{-}$by means of the carboxylic group and the nitrogen atom from the aromatic ring and $\mathrm{glu}^{2-}$ by its carboxylato groups. The asym- metric stretching $v_{\text {asym }}\left(-\mathrm{CO}_{2}^{-}\right)$mode shows shifts up to $33 \mathrm{~cm}^{-1}\left(40 \mathrm{~cm}^{-1}\right.$ in the Raman spectra) to lower wavenumbers when compared with the values reported for the free picolinic acid. Furthermore, the measured values of $\Delta$ $\left[v_{\text {asym }}\left(-\mathrm{CO}_{2}^{-}\right)-v_{\text {sym }}\left(-\mathrm{CO}_{2}^{-}\right)\right]$for the $\mathrm{Sm}\left(281 \mathrm{~cm}^{-1}\right), \mathrm{Eu}$ $\left(283 \mathrm{~cm}^{-1}\right)$ and $\mathrm{Tb}\left(283 \mathrm{~cm}^{-1}\right)$ compounds are further evidence for the presence of carboxylato groups coordinated to the metal centres. The typical stretching $v(\mathrm{C}-\mathrm{N})$ vibrational mode of substituted pyridines appears for the uncoordinated picolinic acid at $1594 \mathrm{~cm}^{-1}$ and shows small shifts (up to $13 \mathrm{~cm}^{-1}$ in the FTIR spectra and up to $30 \mathrm{~cm}^{-1}$ in the Raman spectra) for all compounds, in agreement with N,Ochelation involving the nitrogen atom of the $\mathrm{pic}^{-}$group. The typical stretching $v(\mathrm{C}-\mathrm{O})$ vibrational mode of the carboxylic group of glutaric acid at $1265 \mathrm{~cm}^{-1}$ is shifted for all compounds by $26 \mathrm{~cm}^{-1}$, confirming the bond formed between the deprotonated carboxylic group of glutaric acid and the lanthanide ion.

The thermal decomposition of $\left[\mathrm{Sm}(\mathrm{glu})(\mathrm{pic})\left(\mathrm{H}_{2} \mathrm{O}\right)_{2}\right]$ occurs in a multi-step process from ambient temperature to $800{ }^{\circ} \mathrm{C}$ to yield $\mathrm{Sm}_{2} \mathrm{O}_{3}$ as the final residue (total weight loss: $57 \%$; calculated: $60 \%$ ). The first weight loss of ca. $8.4 \%$ occurs in the $57-230^{\circ} \mathrm{C}$ temperature range (DTG peak at $182^{\circ} \mathrm{C}$ ) and can be attributed to the release of the two coordinated water molecules (calculated weight loss of $8.2 \%$ ). Between 230 and $747{ }^{\circ} \mathrm{C}$ a total weight loss of ca. $49 \%$ corresponds to the thermal decomposition of the organic components (calculated 57\%). The other Ln compounds exhibit similar thermal properties: for $\left[\mathrm{Tb}(\mathrm{glu})(\mathrm{pic})\left(\mathrm{H}_{2} \mathrm{O}\right)_{2}\right]$ the total weight loss was $58 \%$ with a calculated value of $59 \%$ between $72{ }^{\circ} \mathrm{C}$ and $700{ }^{\circ} \mathrm{C}$. For $\left[\mathrm{Eu}(\mathrm{glu})(\mathrm{pic})\left(\mathrm{H}_{2} \mathrm{O}\right)_{2}\right]$ the total weight loss was $57 \%$ with a calculated value of $60 \%$ between $22^{\circ} \mathrm{C}$ and $800^{\circ} \mathrm{C}$.

\section{Photoluminescence}

The excitation spectra of the $\mathrm{Sm}^{3+}, \mathrm{Eu}^{3+}$ and $\mathrm{Tb}^{3+}$ compounds represented in Figure 4 were monitored around the cation's more intense line which can be found at $597 \mathrm{~nm}$ for $\mathrm{Sm}^{3+}, 614 \mathrm{~nm}$ for $\mathrm{Eu}^{3+}$ and $545 \mathrm{~nm}$ for $\mathrm{Tb}^{3+}$. Each spectrum displays a large broad band in the range of 250

Table 3. Analytical and spectroscopic data for $\left[\mathrm{Ln}(\mathrm{glu})(\mathrm{pic})\left(\mathrm{H}_{2} \mathrm{O}\right)_{2}\right]\left(\right.$ where $\mathrm{Ln}=\mathrm{Sm}^{3+}, \mathrm{Tb}^{3+}$ and $\left.\mathrm{Eu}^{3+}\right)$.

\begin{tabular}{|c|c|c|c|c|c|c|c|c|}
\hline \multirow[t]{3}{*}{ Compound } & \multicolumn{3}{|c|}{ Elemental composition $(\%)^{[\mathrm{a}]}$} & \multicolumn{5}{|c|}{ Vibrational data $\left(\mathrm{cm}^{-1}\right)^{[\mathrm{b}]}$} \\
\hline & \multirow[t]{2}{*}{$\mathrm{C}$} & \multirow[t]{2}{*}{$\mathrm{N}$} & \multirow[t]{2}{*}{$\mathrm{H}$} & \multicolumn{3}{|c|}{ Picolinic acid } & \multicolumn{2}{|c|}{ Glutaric acid } \\
\hline & & & & $v_{\text {as }}\left(\mathrm{CO}_{2}\right)$ & $v(\mathrm{CC}), v(\mathrm{CN})$ & $v_{\mathrm{sym}}\left(\mathrm{CO}_{2}\right)$ & $v(\mathrm{CO})$ & $v(\mathrm{C}=\mathrm{O})$ \\
\hline Picolinic acid (Hpic) & - & - & - & $\begin{array}{l}1722 \\
1692\end{array}$ & $\begin{array}{l}1608,1594 \\
1620,1596\end{array}$ & $\begin{array}{l}1344 \\
1358\end{array}$ & - & - \\
\hline Glutaric acid $\left(\mathrm{H}_{2} \mathrm{glu}\right)$ & - & - & - & - & - & - & 1250 & 1697 \\
\hline$\left[\mathrm{Sm}(\mathrm{glu})(\mathrm{pic})\left(\mathrm{H}_{2} \mathrm{O}\right)_{2}\right]$ & $\begin{array}{l}29.20 \\
(30.12)\end{array}$ & $\begin{array}{l}2.71 \\
(3.19)\end{array}$ & $\begin{array}{l}3.23 \\
(3.22)\end{array}$ & $\begin{array}{l}1689 \\
1652\end{array}$ & $\begin{array}{l}1599,1581 \\
1598,1566\end{array}$ & $\begin{array}{l}1408 \\
1351\end{array}$ & 1276 & 1563 \\
\hline$\left[\mathrm{Tb}(\mathrm{glu})(\mathrm{pic})\left(\mathrm{H}_{2} \mathrm{O}\right)_{2}\right]$ & $\begin{array}{l}29.58 \\
(29.55)\end{array}$ & $\begin{array}{l}2.83 \\
(3.16)\end{array}$ & $\begin{array}{l}3.15 \\
(3.13)\end{array}$ & $\begin{array}{l}1691 \\
1654\end{array}$ & $\begin{array}{l}1601,1589 \\
1600,1568\end{array}$ & $\begin{array}{l}1408 \\
1354\end{array}$ & 1276 & 1563 \\
\hline$\left[\mathrm{Eu}(\mathrm{glu})(\mathrm{pic})\left(\mathrm{H}_{2} \mathrm{O}\right)_{2}\right]$ & $\begin{array}{l}29.99 \\
(30.01)\end{array}$ & $\begin{array}{l}2.99 \\
(3.18)\end{array}$ & $\begin{array}{l}3.19 \\
(3.21)\end{array}$ & $\begin{array}{l}1690 \\
1653\end{array}$ & $\begin{array}{l}1600,1584 \\
1600,1567\end{array}$ & $\begin{array}{l}1407 \\
1353\end{array}$ & 1276 & 1563 \\
\hline
\end{tabular}

[a] Calculated values in parentheses. [b] Infrared and Raman (in italics) data. 
$340 \mathrm{~nm}$ and a series of sharp lines characteristic of the $\mathrm{Sm}^{3+}, \mathrm{Eu}^{3+}$ and $\mathrm{Tb}^{3+}$ energy levels. The large broad bands can be ascribed to the excited levels of the ligands ${ }^{[24,26]}$ and are mainly formed of two components, peaking around 275 and $295 \mathrm{~nm}$, being most evident for the $\mathrm{Eu}^{3+}$ and $\mathrm{Tb}^{3+}$ compounds. The assignment of the intra- $4 \mathrm{f}^{5}$ transitions was based on the published literature. ${ }^{[27]}$ Although the ${ }^{7} F_{1}$ level of the $\mathrm{Eu}^{3+}$ complex is populated at room-temperature, we have only explicitly assigned the ${ }^{7} \mathrm{~F}_{1} \rightarrow{ }^{5} \mathrm{D}_{0}$ transition. We also note that the intensity at lower wavelengths $(250$ $260 \mathrm{~nm}$ ) for the $\mathrm{Sm}^{3+}$ complex is artificial due to the correction for the spectroscopic distribution of the lamp intensity (marked with an asterisk in Figure 4).

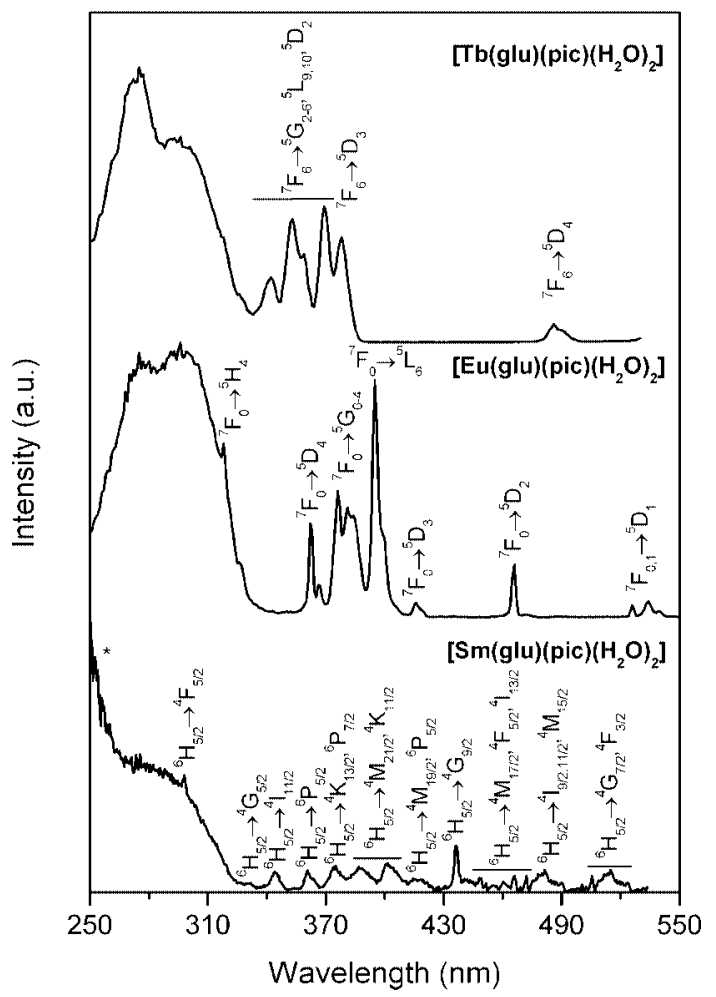

Figure 4. Excitation spectra of $\left[\mathrm{Ln}(\mathrm{glu})(\mathrm{pic})\left(\mathrm{H}_{2} \mathrm{O}\right)_{2}\right]$ monitored at 597,614 , and $545 \mathrm{~nm}$ for the $\mathrm{Sm}^{3+}, \mathrm{Eu}^{3+}$ and $\mathrm{Tb}^{3+}$ complexes, respectively.

Figure 5 shows the emission spectra of the $\mathrm{Sm}^{3+}, \mathrm{Eu}^{3+}$ and $\mathrm{Tb}^{3+}$ compounds. No changes could be detected in the lines of the cations by varying the excitation wavelength, suggesting that the lanthanide centre has only one local environment. The emission spectra of the $\mathrm{Sm}^{3+}, \mathrm{Eu}^{3+}$ and $\mathrm{Tb}^{3+}$ complexes are composed from the intra- $4 \mathrm{f}^{5}\left(\mathrm{Sm}^{3+}\right)$, intra- $4 \mathrm{f}^{6}\left(\mathrm{Eu}^{3+}\right)$ and intra- $4 \mathrm{f}^{8}\left(\mathrm{~Tb}^{3+}\right)$ transitions $\left({ }^{4} \mathrm{G}_{5 / 2} \rightarrow\right.$ ${ }^{6} \mathrm{H}_{5 / 2,7 / 2,9 / 2},{ }^{5} \mathrm{D}_{0} \rightarrow{ }^{7} \mathrm{~F}_{0-4}$, and ${ }^{5} \mathrm{D}_{4} \rightarrow{ }^{7} \mathrm{~F}_{6-3}$, respectively).

The ${ }^{5} \mathrm{D}_{0}\left(\mathrm{Eu}^{3+}\right)$ and ${ }^{5} \mathrm{D}_{4}\left(\mathrm{~Tb}^{3+}\right)$ lifetimes were monitored within the more intense line of the ${ }^{5} \mathrm{D}_{0} \rightarrow{ }^{7} \mathrm{~F}_{2}$ and ${ }^{5} \mathrm{D}_{4} \rightarrow{ }^{7} \mathrm{~F}_{5}$ transitions, respectively, under the excitation which maximises the $\mathrm{Eu}^{3+}$ and $\mathrm{Tb}^{3+}$ emissions. The emission decay curves (not shown) reveal a single-exponential behaviour yielding lifetime values of $0.385 \pm 0.002\left({ }^{5} \mathrm{D}_{0}\right)$

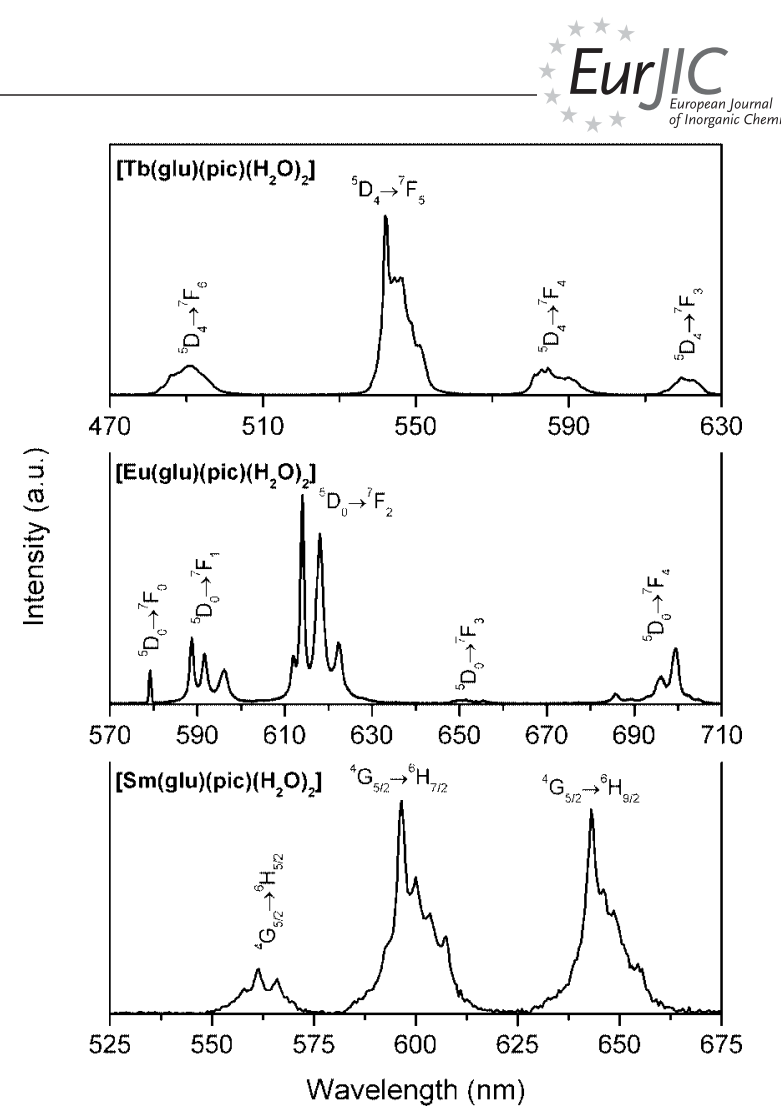

Figure 5. Emission spectra of $\left[\mathrm{Ln}(\mathrm{glu})(\mathrm{pic})\left(\mathrm{H}_{2} \mathrm{O}\right)_{2}\right](\mathrm{Ln}=\mathrm{Sm}, \mathrm{Eu}$, $\mathrm{Tb}$ ), excited at 277, 305 and $277 \mathrm{~nm}$ for the $\mathrm{Sm}^{3+}, \mathrm{Eu}^{3+}$, and $\mathrm{Tb}^{3+}$ complexes, respectively.

and $1.024 \pm 0.005 \mathrm{~ms}\left({ }^{5} \mathrm{D}_{4}\right)$. The quantum efficiency, $q$, of the emission arising from the ${ }^{5} \mathrm{D}_{0}$ level in the $[\mathrm{Eu}(\mathrm{glu})$ (pic) $\left(\mathrm{H}_{2} \mathrm{O}\right)_{2}$ ] complex has been estimated assuming that only nonradiative and radiative processes are essentially involved in the depopulation of the excited state, as already reported ${ }^{[7,28]}$ We obtained a $q$ value of ca. $10 \%$, with a corresponding $k_{\mathrm{r}}$ value of $0.253 \mathrm{~ms}^{-1}$. These values, lifetimes and quantum efficiency values, although lower when compared with those obtained by Sendor et al. for the europium picolinato, ${ }^{[8]}$ are of the same order of magnitude as those obtained for the $\mathrm{Eu}^{3+}$ emission in the 3- hydroxypicolinato $^{[7]}$ and 2-hydroxynicotinato complexes. ${ }^{[29]}$

\section{Conclusions}

A triad of isostructural lanthanide-organic 1D coordination polymers, $\left[\mathrm{Ln}(\mathrm{glu})(\right.$ pic $\left.)\left(\mathrm{H}_{2} \mathrm{O}\right)_{2}\right]$ (where $\mathrm{Ln}=\mathrm{Sm}^{3+}$, $\mathrm{Tb}^{3+}$ and $\mathrm{Eu}^{3+}$ ), were successfully isolated and characterised in the solid-state as homogeneous phase-pure materials. All these compounds share common structural features and show efficient intramolecular aromatic ligand-to-lanthanide energy transfer. These coordination polymers are composed of lanthanide dimers separated by long and flexible glutarato anions. The present results open up interesting prospects for future work concerning the investigation of the photoluminescent behaviour of other picolinic-containing lanthanide-organic polymers in which the length of the flexible ligand could be systematically varied. 


\section{Experimental Section}

General Instrumentation: Infrared spectra were recorded using $\mathrm{KBr}$ disks (Aldrich, 99\%+, spectroscopic grade) with a Matson 7000 FTIR spectrometer. FT-Raman spectra were collected on a Bruker RFS 100 instrument with a Nd:YAG coherent laser $(\lambda=1064 \mathrm{~nm})$. Elemental analyses for $\mathrm{C}, \mathrm{H}$ and $\mathrm{N}$ were performed using a CHNS932 elemental analyser (at the Microanalysis Laboratory of the University of Aveiro) and also an Exeter Analytical CE 440 Elemental Analyser using helium as the purge gas (at the Department of Chemistry, University of Cambridge). Thermogravimetric analyses (TGA) were carried out using a Shimadzu TGA 50 instrument with a heating rate of $10{ }^{\circ} \mathrm{Cmin}^{-1}$ under a continuous air stream with a flow rate of $10 \mathrm{~cm}^{3} \mathrm{~min}^{-1}$. Crystal photographs were taken using a Stemi 2000 stereomicroscope equipped with Carl Zeiss lenses and a high-resolution AxioCam MRc5 digital camera connected to a personal computer. Scanning Electron Microscopy (SEM) images were acquired using a Hitachi S-4100 field emission gun tungsten filament instrument working at $25 \mathrm{kV}$. Samples were prepared by deposition on aluminium sample holders and by carbon coating. The luminescence spectra were recorded at room temperature with a modular double grating excitation spectrofluorimeter with a TRIAX 320 emission monochromator (Fluorolog-3, Jobin Yvon-Spex) coupled to a R928 Hamamatsu photomultiplier by means of the front face acquisition mode. The excitation source was a $450 \mathrm{~W}$ Xe arc lamp. Excitation spectra were corrected from $\lambda=240$ to $600 \mathrm{~nm}$ for the spectral distribution of the lamp intensity using a photodiode reference detector. Emission spectra were also corrected for the spectral response of the monochromators and the detector by using typical correction spectra provided by the manufacturer. The lifetime measurements were acquired with the setup described for the luminescence spectra using a pulsed Xe-Hg lamp (6 $\mu$ s pulse at half width and $20-30 \mu$ s tail).

Syntheses: Chemicals were obtained from commercial sources and used without further purification. Preparation of single crystals of $\left[\mathrm{Sm}(\mathrm{glu})(\mathrm{pic})\left(\mathrm{H}_{2} \mathrm{O}\right)_{2}\right]$ of an appropriate size and stability for singlecrystal X-ray diffraction studies was carried out in a gel formed from $\mathrm{Na}_{2} \mathrm{SiO}_{3} \cdot \mathrm{H}_{2} \mathrm{O}$. A solution of $\mathrm{Na}_{2} \mathrm{SiO}_{3} \cdot 5 \mathrm{H}_{2} \mathrm{O}(0.1 \mathrm{M}, 5 \mathrm{~mL})$ was added dropwise to an aqueous solution $(10 \mathrm{~mL}, \mathrm{pH} 4.3)$ containing glutaric acid and picolinic acid. The mixture was stirred and each test tube, with $5 \mathrm{~mL}$ of solution, was left for $24 \mathrm{~h}$. Afterwards, $\mathrm{Sm}(\mathrm{COO})_{3} \cdot x \mathrm{H}_{2} \mathrm{O}(0.25 \mathrm{mmol})$ was added to the gel. White single crystals of $\left[\mathrm{Sm}(\mathrm{glu})(\mathrm{pic})\left(\mathrm{H}_{2} \mathrm{O}\right)_{2}\right]$ were grown over a period of 4 months.

Isostructural materials, mainly isolated as microcrystalline powders, of picolinic acid and glutaric acid with $\mathrm{Tb}^{3+}$ and $\mathrm{Eu}^{3+}$ were synthesised by adding an aqueous solution of picolinic acid ( $1 \mathrm{mmol})$ to an aqueous solution containing glutaric acid $(1 \mathrm{mmol})$ ( $\mathrm{pH} 6.5$, adjusted with $\mathrm{KOH}$ ) and the corresponding lanthanide salt $\left[\mathrm{Ln}\left(\mathrm{NO}_{3}\right)_{3} \cdot 5 \mathrm{H}_{2} \mathrm{O}, \mathrm{Ln}=\mathrm{Tb}\right.$ and $\left.\mathrm{Eu}\right](0.25 \mathrm{mmol})$. For the compound $\left[\mathrm{Tb}(\mathrm{glu})(\mathrm{pic})\left(\mathrm{H}_{2} \mathrm{O}\right)_{2}\right]$, small crystals could also be manually harvested which allowed unequivocal phase identification by means of the unit cell determination using single-crystal X-ray diffraction data. Phase identification of $\left[\mathrm{Eu}(\mathrm{glu})(\mathrm{pic})\left(\mathrm{H}_{2} \mathrm{O}\right)_{2}\right]$ was performed by employing X-ray powder diffraction (see following sections).

Single-Crystal X-ray Diffraction: A suitable single-crystal of $\left[\mathrm{Sm}(\mathrm{glu})(\mathrm{pic})\left(\mathrm{H}_{2} \mathrm{O}\right)_{2}\right]$ was mounted on a glass fibre using FOMBLIN Y perfluoropolyether vacuum oil (LVAC 25/6) purchased from Aldrich. ${ }^{[30]}$ Data were collected at $180(2) \mathrm{K}$ on a Nonius Kappa CCD area-detector diffractometer (Mo- $K_{\alpha}$ graphite-monochromated radiation, $\lambda=0.7107 \AA$ ) equipped with an Oxford Cryosystems cryostream and controlled with the Collect software package. ${ }^{[31]}$ Images were processed using the software packages
Denzo and Scalepack ${ }^{[32]}$ and data were corrected for absorption by the empirical method employed in Sortav. ${ }^{[33,34]}$ The structure was solved by direct methods with SHELXS-97 ${ }^{[35]}$ and refined by fullmatrix least-squares on $F^{2}$ using SHELXL-97. ${ }^{[36]}$ All non-hydrogen atoms were directly located from difference Fourier maps and refined with anisotropic displacement parameters.

Even though the vast majority of the hydrogen atoms bound to carbon were markedly visible in the difference Fourier maps, they were instead located in their idealised positions using appropriate HFIX instructions in SHELXL (43 for the aromatic and 23 for the $-\mathrm{CH}_{2}-$ carbon atoms) and included in subsequent refinement cycles in riding-motion approximation with isotropic thermal displacements parameters ( $U_{\text {iso }}$ ) fixed at 1.2 times $U_{\text {eq }}$ of the carbon atom to which they are each attached. Hydrogen atoms associated with the coordinated water molecules were directly located from difference Fourier maps and included in the final structural model with the $\mathrm{O}-\mathrm{H}$ and $\mathrm{H} \cdots \mathrm{H}$ distances restrained to $0.95(1) \AA$ and $1.55(1) \AA$, respectively (in order to ensure a chemically reasonable geometry for these molecules), and using a riding model with an isotropic displacement parameter fixed at 1.5 times $U_{\text {eq }}$ of the atom to which they are each attached. The last difference Fourier map synthesis showed the highest peak $\left(0.892 \mathrm{e}^{-3}\right)$ and deepest hole $\left(-0.949 \mathrm{e}^{-3}\right)$ located at $1.51 \AA$ from $\mathrm{C}(5)$ and $0.82 \AA$ from $\operatorname{Sm}(1)$, respectively.

A single-crystal of $\left[\mathrm{Tb}(\mathrm{glu})(\mathrm{pic})\left(\mathrm{H}_{2} \mathrm{O}\right)_{2}\right]$ was also investigated using the same experimental conditions as for the $\mathrm{Sm}^{3+}$ compound (see above). A full data set (data completeness $99.7 \%$ ), collected in the $1.00^{\circ} \leq \theta \leq 32.03^{\circ}$ range, consisted of 13480 integrated reflections $\left(R_{\text {int }}=0.065\right.$ in $P 2$ symmetry) of which 4800 are unique. A subset of 8701 reflections was used for unit cell refinement, with the final parameters converging to: $a=8.4304$ (2) $\AA, b=13.3040(3) \AA, c=$

Table 4. Crystal and structure refinement data for [Sm(glu)(pic) $\left.\left(\mathrm{H}_{2} \mathrm{O}\right)_{2}\right]$.

\begin{tabular}{|c|c|}
\hline Formula & $\mathrm{C}_{11} \mathrm{H}_{14} \mathrm{NO}_{8} \mathrm{Sm}$ \\
\hline Formula weight & 438.58 \\
\hline Crystal system & monoclinic \\
\hline Space group & $P 2_{1} / c$ \\
\hline$a[\AA ̊ \cap]$ & $11.855(2)$ \\
\hline$b[\AA]$ & $13.477(3)$ \\
\hline$c[\AA]$ & $8.4804(17)$ \\
\hline$\beta\left[^{\circ}\right]$ & $96.42(3)$ \\
\hline Volume $\left[\AA^{3}\right]$ & $1346.4(5)$ \\
\hline$Z$ & 4 \\
\hline$D_{\mathrm{c}}\left[\mathrm{g} \mathrm{cm}^{-3}\right]$ & 2.164 \\
\hline$\mu\left(\mathrm{Mo}-K_{\alpha}\right)\left[\mathrm{mm}^{-1}\right]$ & 4.401 \\
\hline$F(000)$ & 852 \\
\hline Crystal size $[\mathrm{mm}]$ & $0.07 \times 0.05 \times 0.02$ \\
\hline Crystal type & colourless blocks \\
\hline$\theta$ range $\left[{ }^{\circ}\right]$ & 3.78 to 27.51 \\
\hline Index ranges & $\begin{array}{l}-15 \leq h \leq 15 \\
-17 \leq k \leq 16 \\
-10 \leq l \leq 10\end{array}$ \\
\hline Reflections collected & 13389 \\
\hline Independent reflections & $3076\left(R_{\text {int }}=0.0630\right)$ \\
\hline Final $R$ indices $[I>2 \sigma(I)]^{[\mathrm{a}, \mathrm{b}]}$ & $\begin{array}{l}R_{1}=0.0307 \\
w R_{2}=0.0660\end{array}$ \\
\hline Final $R$ indices (all data) ${ }^{[\mathrm{a}, \mathrm{b}]}$ & $\begin{array}{l}R_{1}=0.0409 \\
w R_{2}=0.0705\end{array}$ \\
\hline Weighting scheme $e^{[c]}$ & $\begin{array}{l}m=0.0247 \\
n=3.7121\end{array}$ \\
\hline Largest diff. peak and hole [e $\AA^{-3}$ ] & 0.892 and -0.949 \\
\hline
\end{tabular}

[a] $R_{1}=\Sigma|| F_{\mathrm{o}}|-| F_{\mathrm{c}}\left|/ \sum\right| F_{\mathrm{o}} \mid$. [b] $w R_{2}=\sqrt{ } \sum\left[w\left(F_{\mathrm{o}}{ }^{2}-F_{c}{ }^{2}\right)^{2}\right] / \Sigma\left[w\left(F_{\mathrm{o}}{ }^{2}\right)^{2}\right]$. [c] $w=1 /\left[\sigma^{2}\left(F_{\mathrm{o}}{ }^{2}\right)+(m P)+n P\right]$ where $P=\left(F_{\mathrm{o}}{ }^{2}+2 F_{\mathrm{c}}{ }^{2}\right) / 3$. 
$11.9536(2) \AA, \beta=96.4275(14)^{\circ}$ and $V=1332.27(5) \AA^{3}$ [crystal mosaicity of $\left.0.500(2)^{\circ}\right]$.

Information concerning crystallographic data collection and structure refinement details for $\left[\mathrm{Sm}(\mathrm{glu})(\mathrm{pic})\left(\mathrm{H}_{2} \mathrm{O}\right)_{2}\right]$ is summarised in Table 4. Selected bond lengths and angles for the $\mathrm{Sm}^{3+}$ coordination environment are given in Table 1. Hydrogen bonding geometric details are provided in Table 2.

CCDC-611302 (for $\left[\mathrm{Sm}(\mathrm{glu})(\mathrm{pic})\left(\mathrm{H}_{2} \mathrm{O}\right)_{2}\right]$ contains the supplementary crystallographic data for this paper. These data can be obtained free of charge from The Cambridge Crystallographic Data Centre via www.ccdc.cam.ac.uk/data_request/cif.

Powder X-ray Diffraction: Powder X-ray diffraction data were collected on a X'Pert MPD Philips diffractometer $\left(\mathrm{Cu}-K_{\alpha} \mathrm{X}\right.$-radiation, $\lambda=1.54060 \AA$ ) equipped with an $\mathrm{X}^{\prime}$ Celerator detector, graphitemonochromated radiation and a flat-plate sample holder in a Bragg-Brentano para-focusing optics configuration $(40 \mathrm{kV}$, $50 \mathrm{~mA}$ ). Intensity data were collected in a continuous scanning mode in the ca. $3^{\circ} \leq 2 \theta \leq 70^{\circ}$ angular range.

The collected powder X-ray diffraction pattern for [Eu(glu)(pic) $\left(\mathrm{H}_{2} \mathrm{O}\right)_{2}$ ] was indexed by means of the routines provided with the software program DICVOL04 ${ }^{[37]}$ and by employing the first 20 well-resolved reflections (located using the derivative-based peak search algorithm provided with Fullprof.2k) ${ }^{[38,39]}$ and a fixed absolute error on each line of $0.03^{\circ} 2 \theta$. Preliminary unit cell metrics were calculated with high figures-of-merit: $M(20)^{[40]}=44.4$ and $F(20)^{[41]}=97.6$; zero shift of $0.0246^{\circ}$.

A Le Bail ${ }^{[42]}$ whole-powder-diffraction-pattern profile fitting in the space group $P 2_{1} / c$ (systematic absences unequivocally identified using CHECKCELL ${ }^{[43]}$ ) was performed with the FullProf.2k software package. The fit provided as in Figure S1 in the Supporting Information was obtained by using a typical pseudo-Voigt peakshape function and, in the last stages of the fitting process the unit cell parameters and typical profile parameters, such as scale factor, zero shift, Caglioti function values and two asymmetry parameters were allowed to refine. Fixed background points were used. Refined unit cell parameters: $a=12.025(1) \AA, b=13.376(1) \AA, c=$ 8.480(1) $\AA, \beta=96.862(5)^{\circ}\left(R_{\text {Bragg }}=1.54 \%\right.$ and $\left.\chi^{2}=6.81\right)$.

Supporting Information (see also the footnote on the first page of this article): Le Bail whole-powder-diffraction-pattern profile fitting in the $P 2_{1} / c$ space group for compound $\left[\mathrm{Eu}(\mathrm{glu})(\mathrm{pic})\left(\mathrm{H}_{2} \mathrm{O}\right)_{2}\right]$. Optical and SEM images of crystals belonging to the compounds containing $\mathrm{Tb}^{3+}$ and $\mathrm{Sm}^{3+}$.

\section{Acknowledgments}

We are grateful to Fundação para a Ciência e Tecnologia (FCT) for their general financial support (POCI/QUI/58377/2004), for support by FEDER and for the $\mathrm{PhD}$ and post-doctoral research grants SFRH/BD/17968/2004 (to P. G.) and SFRH/BPD/14954/ 2004 (to P. S.-S.), respectively.

[1] a) G. A. Ozin, A. C. Arsenault in Nanochemistry, RSC, Cambridge, 2005; b) Nanoparticles (Ed.: G. Schmid), Wiley-VCH, Weinheim, 2004; c) The Chemistry of Nanomaterials (Eds.: C. N. R. Rao, A. Müller, A. K. Cheetham), Wiley-VCH, Weinheim, 2003; d) A. C. Jones, P. O'Brien in CVD of Compound Semiconductors, VCH, Weinheim, 1997; e) C. Sanchez, B. Lebeau, F. Chaput, J. P. Boilot, Adv. Mater. 2003, 15, 19691994; f) F. A. Cotton, J. Chem. Soc. Dalton Trans. 2000, 19611968; g) P. H. Dinolfo, J. T. Hupp, Chem. Mater. 2001, 13, 3113-3125.
[2] S. Kitagawa, R. Kitaura, S. Noro, Angew. Chem. Int. Ed. 2004, 43, 2334-2375.

[3] a) P. O'Brien, R. Nomura, J. Mater. Chem. 1995, 5, 1761-1773; b) M. Bochmann, Chem. Vap. Deposition 1996, 2, 88; c) T. Trindade, P. O'Brien, X. Zhang, Chem. Mater. 1997, 9, 523-530; d) O. C. Monteiro, H. I. S. Nogueira, T. Trindade, M. Motevalli, Chem. Mater. 2001, 13, 2103-2111; e) M. Green, P. Prince, M. Gardener, J. Steed, Adv. Mater. 2004, 16, 994-996.

[4] a) E. Kiss, A. Benyei, T. Kiss, Polyhedron 2003, 22, 27-33; b) S. Yano, M. Nakai, F. Sekiguchi, M. Obata, M. Kato, M. Shiro, I. Kinoshita, M. Mikuriya, H. Sakurai, C. Orvig, Chem. Lett. 2002, 9, 916-917; c) C. Y. Sun, X. J. Zheng, L. P. Jin, J. Mol. Struct. 2003, 646, 201-210; d) R. March, W. Clegg, R. A. Coxall, L. Cucurull-Sanchez, L. Lezama, T. Rojo, P. GonzalezDuarte, Inorg. Chim. Acta 2003, 353, 129-138; e) A. Shaver, J. B. NG, D. A. Hall, B. S. Lum, B. I. Posner, Inorg. Chem. 1993, 32, 3109-3113; f) S. Yano, M. Nakai, F. Sekiguchi, M. Obata, M. Kato, M. Shiro, I. Kinoshita, M. Mikuriya, H. Sakurai, C. Orvig, Chem. Lett. 2002, 9, 916-917; g) R. K. Barman, S. K. Singh, B. K. Das, J. Chem. Crystallogr. 2002, 32, 369375; h) M. Palicova, P. Segl'a, D. Miklos, M. Kopcova, M. Melnik, B. Dudova, D. Hudecova, T. Glowiak, Polyhedron 2000, 19, 2689-2695.

[5] a) W. P. Griffith, H. I. S. Nogueira, A. J. P. White, D. J. Williams, Polyhedron 1997, 16, 1323-1329; b) W. P. Griffith, H. I. S. Nogueira, B. C. Parkin, R. N. Sheppard, A. J. P. White, D. J. Williams, J. Chem. Soc. Dalton Trans. 1995, 1775-1781; c) W. P. Griffith, C. A. Pumphrey, J. T. Rainey, J. Chem. Soc. Dalton Trans. 1986, 1125-1128.

[6] a) S. M. O. Quintal, H. I. S. Nogueira, V. Félix, M. G. B. Drew, New J. Chem. 2000, 24, 511-517; b) S. M. O. Quintal, H. I. S. Nogueira, V. Félix, M. G. B. Drew, Polyhedron 2002, 21, 2783 2791; c) P. I. Girginova, F. A. A. Paz, H. I. S. Nogueira, N. J. O. Silva, V. S. Amaral, J. Klinowski, T. Trindade, J. Mol. Struct. 2005, 737, 221-229; d) P. I. Girginova, F. A. A. Paz, H. I. S. Nogueira, N. J. O. Silva, V. S. Amaral, J. Klinowski, T. Trindade, Polyhedron 2005, 24, 563-569.

[7] P. C. R. Soares-Santos, H. I. S. Nogueira, V. Félix, M. G. B. Drew, R. A. Sá Ferreira, L. D. Carlos, T. Trindade, Chem. Mater. 2003, 15, 100-108.

[8] D. Sendor, M. Hilder, T. Juestel, P. Junk, U. Kynast, New J. Chem. 2003, 27, 1070-1077.

[9] O. Guillou, C. Daiguebonne, Lanthanide-containing coordination polymers in Handbook on the Physics and Chemistry of Rare Earths (Eds.: K. A. Gschneidner Jr, J.-C. G. Bünzli, V. K. Pecharsky), 2005, 34, p. 359.

[10] F. H. Allen, Acta Crystallogr., Sect. B 2002, 58, 380-388.

[11] F. H. Allen, W. D. S. Motherwell, Acta Crystallogr., Sect. B 2002, 58, 407-422.

[12] J. Legendziewicz, B. Keller, I. Turowska-Tyrk, W. Wojciechowski, New J. Chem. 1999, 23, 1097-1103.

[13] L. P. Zhang, Y. H. Wan, L. P. Jin, J. Mol. Struct. 2003, 646, 169-178.

[14] T. Glowiak, J. Legendziewicz, C. N. Dao, E. Huskowska, J. Less-Common Met. 1987, 134, 153-168.

[15] P. Thomas, J. C. Trombe, J. Chem. Crystallogr. 2000, 30, 633639.

[16] B. Benmerad, A. Guehria-Laidoudi, S. Dahaoui, C. Lecomte, Acta Crystallogr., Sect. C 2004, 60, M119-M122.

[17] R. Vaidhyanathan, S. Natarajan, C. N. R. Rao, J. Solid State Chem. 2004, 177, 1444-1448.

[18] T. Glowiak, D. C. Ngoan, J. Legendziewicz, Acta Crystallogr., Sect. C 1986, 42, 1494-1496.

[19] F. Serpaggi, G. Ferey, J. Mater. Chem. 1998, 8, 2737-2741.

[20] F. Serpaggi, G. Ferey, J. Mol. Struct. 2003, 656, 201-206.

[21] B. Benmerad, A. Guehria-Laidoudi, F. Balegroune, H. Birkedal, G. Chapuis, Acta Crystallogr., Sect. C 2000, 56, 789-792.

[22] A. Dolbecq, P. Mialane, L. Lisnard, J. Marrot, F. Secheresse, Chem. Eur. J. 2003, 9, 2914-2920. 
[23] P. C. R. Soares-Santos, H. I. S. Nogueira, V. Felix, M. G. B. Drew, R. A. S. Ferreira, L. D. Carlos, T. Trindade, Inorg. Chem. Commun. 2003, 6, 1234-1238.

[24] D. Sendor, M. Hilder, T. Juestel, P. C. Junk, U. H. Kynast, New J. Chem. 2003, 27, 1070-1077.

[25] J. F. Ma, N. H. Hu, J. Z. Ni, Polyhedron 1996, 15, 1797-1799.

[26] P. C. R. Soares-Santos, F. A. Almeida Paz, R. A. Sa Ferreira, J. Klinowski, L. D. Carlos, T. Trindade, H. I. S. Nogueira, Polyhedron 2006, 25, 2471-2482.

[27] a) M. D. Faucher, P. A. Tanner, J. Phys. Condens. Matter. 2006, 18, 8503-8522; b) J. B. Gruber, B. Zandi, M. F. Reid, Phys. Rev. $B$ 1999, 60, 15643-15653; c) J.-P. R. Wells, M. Yamaga, T. P. J. Han, H. G. Gallagher, M. Honda, Phys. Rev. B 1999, 60, 3849 3855; d) A. R. Devi, C. K. Jayasankar, M. F. Reid, Phys. Rev. $B$ 1994, 49, 12551-12555.

[28] J. A. Fernandes, R. A. Sá Ferreira, M. Pillinger, L. D. Carlos, J. Jepsen, A. Hazell, P. Ribeiro-Claro, I. S. Gonçalves, J. Lumin. 2005, 113, 50-63.

[29] P. C. R. Soares-Santos, H. I. S. Nogueira, J. Rocha, V. Félix, M. G. B. Drew, R. A. Sá Ferreira, L. D. Carlos, T. Trindade, Polyhedron 2003, 22, 3529-3539.

[30] T. Kottke, D. Stalke, J. Appl. Crystallogr. 1993, 26, 615-619.

[31] R. Hooft, Collect: Data Collection Software, Delft, The Netherlands, Nonius B. V., 1998.

[32] Z. Otwinowski, W. Minor, in Methods in Enzymology, vol. 276 (Eds.: C. W. Carter Jr, R. M. Sweet), Academic Press, New York, 1997, p. 307.

[33] R. H. Blessing, Acta Crystallogr., Sect. A 1995, 51, 33-38.
[34] R. H. Blessing, J. Appl. Crystallogr. 1997, 30, 421.

[35] G. M. Sheldrick, SHELXS-97, Program for Crystal Structure Solution, University of Göttingen (Germany), 1997.

[36] G. M. Sheldrick, SHELXL-97, Program for Crystal Structure Refinement, University of Göttingen (Germany), 1997.

[37] A. Boultif, D. Louer, J. Appl. Crystallogr. 2004, 37, 724-731.

[38] J. Rodriguez-Carvajal, FULLPROF - A Program for Rietveld Refinement and Pattern Matching Analysis, Abstract of the Satellite Meeting on Powder Diffraction of the XV Congress of the IUCR, Toulouse, France, 1990, p. 127.

[39] T. Roisnel, J. Rodriguez-Carvajal, WinPLOTR (rel. June 2005) - A Windows Tool for Powder Diffraction Pattern Analysis. Materials Science Forum, Proceedings of the Seventh European Powder Diffraction Conference (EPDIC 7) (Eds.: R. Delhez, E. J. Mittenmeijer), 2000, p. 118-123.

[40] A. Boultif, D. Louer, J. Appl. Crystallogr. 1991, 24, 987-993.

[41] D. Louer, in Automatic Indexing: Procedures and Applications, Accuracy in Powder Diffraction II, Gaithersburg, MD, USA, 1992, pp. $92-104$.

[42] A. Lebail, H. Duroy, J. L. Fourquet, Mater. Res. Bull. 1988, $23,447-452$.

[43] J. Laugier, B. Bochu, CHECKCELL - A Software Performing Automatic Cell/Space Group Determination, Collaborative Computational Project Number 14 (CCP14), Laboratoire des Matériaux et du Génie Physique de l'Ecole Supérieure de Physique de Grenoble (INPG), France, 2000.

Received: December 19, 2006 Published Online: July 18, 2007 